FITRAH Jurnal Kajian Ilmu-ilmu Keislaman

Vol. 03 No. 1 Juni 2017

e-ISSN : 2460-2345, p-ISSN: 2442-6997

Web: jurnal.iain-padangsidimpuan.ac.id/index.php/F

\title{
MEMAKNAI PUTUS ASA DALAM PARADIGMA HENTI
}

\author{
HUSNIAH RAMADHANI PULUNGAN \\ Dosen Universitas Muhammadiyah Tapanuli Selatan \\ Email: husniahpulungan@gmail.com
}

\begin{abstract}
Despair caused by the loss of hope that makes a person stop hoping. Islam forbids it, because God has promised it easy for His servants who did not despair and continue to be patient in the face the tests of life. At the stop words are lexem HENTI which when analyzed morphologically based linguistics will be able to give a detailed understanding about the lexem. The analysis conducted by derivational and inflectional this will result ideosincretics of rules were found. Thus, an understanding of morphological standpoint this will provide benefits in the needs-oriented communication on the positive things. Finally, communication with the use of positive diction will encourage someone to have a mindset and a way of life that is better aligned with the values of Islam.
\end{abstract}

Keywords: despair, paradigm, lexem, stopping

\begin{abstract}
Abstrak
Putus asa terjadi akibat hilangnya harapan yang membuat seseorang menjadi berhenti berharap. Islam melarang hal tersebut karena Allah telah menjanjikan kemudahan bagi hambaNya yang tidak berputus asa dan senantiasa bersabar dalam menghadapi ujian kehidupan. Pada kata berhenti terdapat leksem HENTI yang bila dianalisis secara morfologis berdasarkan ilmu linguistik akan dapat memberikan pemahaman secara mendetil mengenai leksem tersebut. Analisis yang dilakukan secara derivasional dan infleksional ini akan menghasilkan ideosinkretis dari kaidah-kaidah yang ditemukan. Dengan demikian, pemahaman dari sudut pandang morfologi ini akan memberikan manfaat dalam kebutuhan berkomunikasi yang berorientasi pada hal-hal yang positif. Akhirnya, komunikasi dengan penggunaan diksi positif akan mendorong seseorang untuk memiliki pola pikir dan cara hidup yang lebih baik sesuai dengan nilai-nilai Islam.
\end{abstract}

Kata Kunci: Putus Asa, Paradigma, Leksem, Henti

\section{PENDAHULUAN}

Ajaran Islam telah mengantarkan pemeluknya untuk memiliki tingkah laku yang diformulasikan melalui sumber ajaran itu sendiri. Alquran sebagai 
FITR AH Jurnal Kajian Ilmu-ilmu Keislaman

Vol. 03 No. 1 Juli 2017

sumber ajaran menjadi sangat penting untuk dilihat sehingga aktivitas manusia di muka bumi ini tidak melenceng daro kosep ilahi. Kemudian, sebagai manusia yang diliputi oleh sifat-sifat yang tidak baik sangat berpeluang untuk melenceng dari konsep tersebut.

Di antara sifat yang dimiliki oleh manusia adalah terjadinya putus asa akibat hilangnya harapan yang membuat seseorang menjadi berhenti berharap. Islam melarang hal tersebut karena Allah telah menjanjikan kemudahan bagi hambaNya yang tidak berputus asa dan senantiasa bersabar dalam menghadapi ujian kehidupan. Pada kata berhenti terdapat leksem HENTI yang bila dianalisis secara morfologis berdasarkan ilmu linguistik akan dapat memberikan pemahaman secara mendetil mengenai leksem tersebut. Analisis yang dilakukan secara derivasional dan infleksional ini akan menghasilkan ideosinkretis dari kaidah-kaidah yang ditemukan. Dengan demikian, pemahaman dari sudut pandang morfologi ini akan memberikan manfaat dalam kebutuhan berkomunikasi menjadi berorientasi pada hal-hal yang positif. Akhirnya, komunikasi dengan penggunaan diksi positif akan mendorong seseorang untuk memiliki pola pikir dan cara hidup yang lebih baik sesuai dengan nilai-nilai Islam.

Guna menghindari prilaku manusia agar tidak sampai berputus asa dalam menyelesaikan persoalan hidup melalui bahasa berkomunikasi maka tulisan ini akan mencoba memberikan tawaran sebagai salah satu solusi atau alternatif bagi manusia.

\section{PEMBAHASAN}

\section{Larangan Berputus Asa}

Islam adalah agama yang rahmatan lil 'alamin karena Allah swt. memiliki rahmat yang tak terbatas bagi hambaNya. Demikian pula seharusnya, seorang hamba tidak boleh berputus asa akan rahmat Allah swt yang tak terhingga tersebut. Definisi putus asa dalam KBBI Online adalah memiliki habis (hilang) harapan; tidak mempunyai harapan lagi. Pada saat seseorang sudah memiliki hilang harapan ataupun tidak mempunyai harapan lagi, maka seseorang tersebut dapat dikatakan telah berhenti berharap. Sikap putus asa yang terjadi karena munculnya sikap berhenti berharap sangat dilarang dalam Islam. Sikap tersebut terjadi karena hilangnya keimanan, padahal Allah telah menjanjikan bahwa sesungguhnya pertolongan Allah itu amat dekat, sesungguhnya sesudah 
kesulitan itu ada kemudahan, Allah tidak menghendaki kesukaran bagi hambaNya, dan akhirnya bagi orang yang sabar ada pahala dan kebaikan yang begitu besar.

Berdasarkan sejarah Islam, Allah telah membuktikan janjinya tanpa ada yang meleset. Di antara janji Allah yang dapat dijadikan contoh untuk mengatasi sikap hilang harapan tersebut telah terdokumentasikan dalam Al qur'an melalui kisah-kisah para Nabi terdahulu. Kisah-kisah ini telah banyak membuktikan betapa besar rahmat dan kasih sayang Allah pada hambaNya yang tidak pernah berputus asa. Berikut pemaparannya.

\section{Doa Nabi Nuh as.}

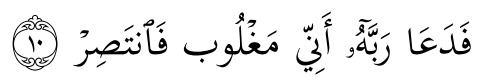

Artinya: Maka dia mengadu kepada Tuhannya: "bahwasanya aku ini adalah orang yang dikalahkan, oleh sebab itu menangkanlah (aku)". (Q.S. AlQamar:10)

Jawaban Allah swt. atas doa Nabi Nuh as.

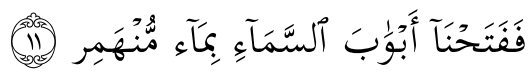

Artinya: Maka Kami bukakan pintu-pintu langit dengan (menurunkan) air yang tercurah. (Q.S. Al-Qamar:11)

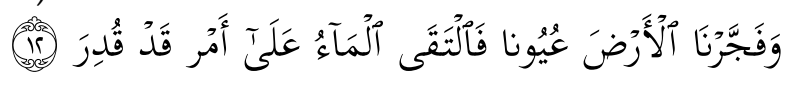

Artinya: Dan Kami jadikan bumi memancarkan mata air-mata air, maka bertemulah air-air itu untuk suatu urusan yang sungguh telah ditetapkan. (Q.S. Al-Qamar:12)

Doa Nabi Zakaria as.

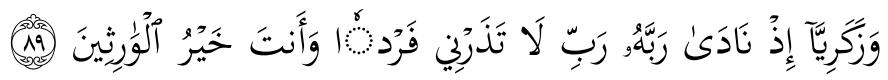

Artinya: Dan (ingatlah kisah) Zakaria, tatkala ia menyeru Tuhannya: "Ya Tuhanku janganlah Engkau membiarkan aku hidup seorang diri dan Engkaulah Waris Yang Paling Baik. (Q.S. Al-Anbiya:89)

Jawaban Allah swt. atas doa Nabi Zakaria as.

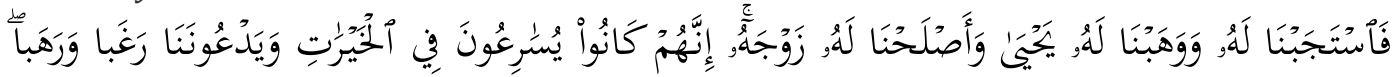

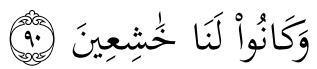

Artinya: Maka Kami memperkenankan doanya, dan Kami anugerahkan kepadanya Yahya dan Kami jadikan istrinya dapat mengandung. Sesungguhnya mereka adalah orang-orang yang selalu bersegera dalam (mengerjakan) perbuatan-perbuatan yang baik dan mereka berdoa 
FITR AH Jurnal Kajian Ilmu-ilmu Keislaman

Vol. 03 No. 1 Juli 2017

kepada Kami dengan harap dan cemas. Dan mereka adalah orang-orang yang khusyuk kepada Kami. (Q.S. Al-Anbiya:90)

Doa Nabi Ayyub as.

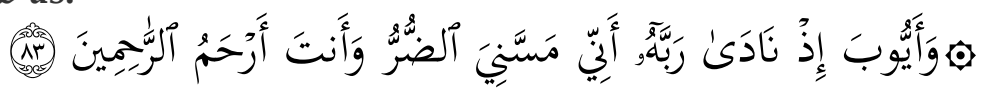

Artinya: Dan (ingatlah kisah) Ayub, ketika ia" menyeru Tuhannya: "(Ya Tuhanku), sesungguhnya aku telah ditimpa penyakit dan Engkau adalah Tuhan Yang Maha Penyayang di antara semua penyayang". (Q.S. Al-Anbiya:83)

Jawaban Allah swt. atas doa Nabi Ayyub as.

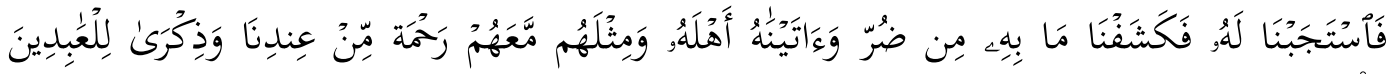

Artinya: Maka Kami pun memperkenankan seruannya itu, lalu Kami lenyapkan penyakit yang ada padanya dan Kami kembalikan keluarganya kepadanya, dan Kami lipat gandakan bilangan mereka, sebagai suatu rahmat dari sisi Kami dan untuk menjadi peringatan bagi semuayang menyembah Allah. (Q.S. Al-Anbiya:84)

Doa Nabi Sulaiman as.

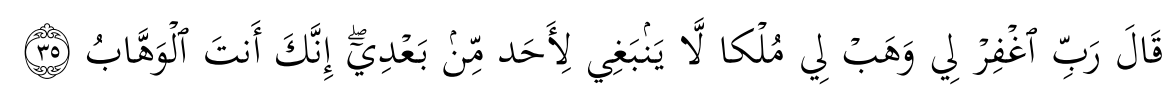

Artinya: Ia berkata: "Ya Tuhanku, ampunilah aku dan anugerahkanlah kepadaku kerajaan yang tidak dimiliki oleh seorang juapun sesudahku, sesungguhnya Engkaulah Yang Maha Pemberi". (Q.S. Saad:35)

Doa Nabi Ibrahim as.

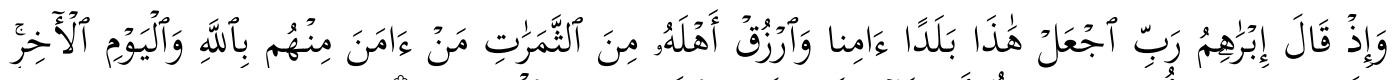

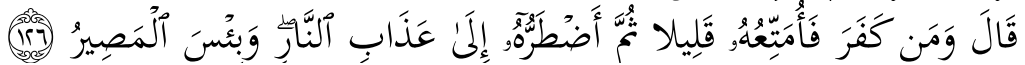

Artinya: Dan (ingatlah), ketika Ibrahim berdoa: YaTuhanku, jadikanlah negeri ini negeri yang aman sentosa, dan berikanlah rezeki dari buah-buahan kepada penduduknya yang beriman di antara mereka kepada Allah dan hari kemudian. Allah berfirman: "Dan kepada orang yang kafir pun Aku beri kesenangan sementara, kemudian Aku paksa ia menjalani siksa neraka dan itulah seburuk-buruk tempat kembali". (Q.S. AlBaqarah:126)

Berdasarkan ayat-ayat di atas, maka dapat dinyatakan bahwa tidak ada alasan bagi orang yang beriman untuk berhenti berharap yang berujung pada keputusasaan. Karena Allah berfirman yang berbunyi: 


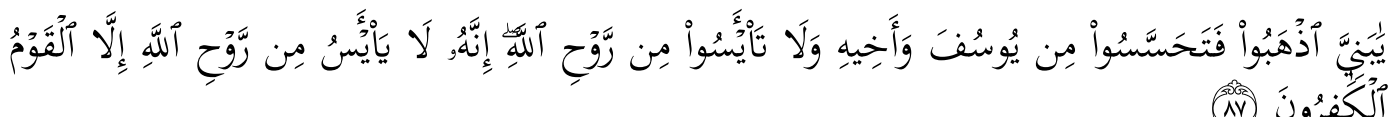

Artinya: Hai anak-anakku, pergilah kamu, maka carilah berita tentang Yusuf dan saudaranya dan jangan kamu berputus asa dari rahmat Allah. Sesungguhnya tiada berputus asa dari rahmat Allah, melainkan kaum yang kafir". (Q.S. Yusuf:87)

Sesuai dengan firman Allah di atas, maka dapat dinyatakan bahwa orangorang yang beriman dilarang untuk berputus asa yang membuat berhenti berharap akan kasih sayang Allah. Mengingat kata berhenti berasal dari leksem HENTI dalam ilmu linguistik, ada baiknya untuk lebih memahami seluk-beluk proses leksem ini secara morfologis, maka selanjutnya akan dijelaskan dalam pemaparan berikut.

\section{Morfologi Infleksional dan Morfologi Derivasional}

Morfologi secara tradisional dibagi menjadi dua cabang infleksi dan derivasi. Kedua hal ini biasanya dipandang secara terpisah; infeksi adalah bagian dari sintaksis, sementara derivasi adalah bagian dari leksem. ${ }^{1}$ Kemudian, fleksi atau morfologi infleksional dalam pandangan Verhaar adalah proses morfemis yang diterapkan pada kata sebagai unsur leksikal yang sama, sedangkan derivasi, atau morfologi derivasional adalah proses morfemis yang mengubah kata sebagai unsur leksikal tertentu menjadi unsur leksikal yang lain.. ${ }^{2}$ Dengan demikian, morfologi infleksional dan morfologi derivasional adalah proses morfemis yang berperan besar dalam mengubah kata dan unsur leksikalnya. Proses infleksi dan derivasi pada setiap bahasa memiliki keunikan tersendiri yang dapat menunjukkan tunggal atau jamak, kala waktu, gender, bahkan perubahan kelas kata.

Morfem derivasional menurut Yule digunakan untuk membuat katakata baru dalam bahasa dan sering digunakan untuk membuat kata-kata yang berbeda kategori gramatikalnya dari stem. ${ }^{3}$ Dengan demikian, penambahan morfem derivasional-ness mengubah adjektif good 'baik' menjadi goodness 'kebaikan'. Morfem infleksional tidak digunakan untuk menghasilkan kata-kata baru dalam bahasa Inggris, tapi lebih mengacu pada aspek fungsi gramatikal dari sebuah kata. Morfem infleksional digunakan untuk menunjukkan apakah

${ }^{1}$ Laurie Bauer, Introducing Linguistic Morphology (Edinburgh: Edinburgh University Press, 2003), hlm. 
FITR AH Jurnal Kajian Ilmu-ilmu Keislaman

Vol. 03 No. 1 Juli 2017

sebuah kata itu jamak atau tunggal, apakah past tense atau bukan, dan apakah perbandingan (komparatif) atau bentuk posesif. Bahasa Inggris hanya memiliki delapan morfem infleksional yang dapat dilihat sebagai berikut:

Let me tell you about Jim's two sisters.

One likes to have fun and is always laughing.

The other liked to study and has always taken things seriously.

One is the loudest person in the house and the other is quieter than a mouse.

Berdasarkan contoh-contoh di atas, dapat dilihat bahwa terdapat dua infleksi,-'s (posesif) dan $-s$, (jamak) yang menyatu pada nomina. Ada empat yang menyatu dengan verba -s (orang ketiga tunggal dalam kala present), -ing (present participle), -ed (past tense) dan -en (past participle). Ada dua infleksi, -est (superlatif) dan -er (komparatif) yang menyatu dengan adjektif. Catatan bahwa di dalam Bahasa Inggris, semua morfem infleksional ditandai dengan adanya sufiks.

$$
\begin{aligned}
& \text { Nomina +-'s, -s } \\
& \text { Verba + -s, -ing, -ed, -en } \\
& \text { Adjectif + -est, -er }
\end{aligned}
$$

Sufiks derivasional merupakan pembentukan kata-kata baru. Sebagian besar diantaranya mengandung bunyi vokal (baik di awal dari sufiks maupun setelah konsonannya), dan hal itu turut membantu pada pemanjangan suku kata dari penghasilan akar kata-kata yang muncul. ${ }^{4} \mathrm{Hal}$ ini membawa pada sebuah interpretasi yang sangat umum ((aksi dari), (yang menghasilkan atau berhubungan pada), dan sebagainya), yang mengkombinasikan pada hal-hal yang dilekatinya. Dengan demikian, hal ini dapat dilihat pada contoh berikut:

-age di dalam akhiran kata kerja : batt+age, verniss+age

-ure di dalam: pel+ure, racl+ure

-aire di dalam: scol+aire, aliment+aire

-ique di dalam: desert+ique, tyrann+ique

Sufiks fleksional mengacu pada susunan gramatikal (jenis kelamin, jumlah, orang, waktu, dan modal), seperti: $-s$, mengacu pada jamak pada nomina dan adjektif dan $-e$, penanda femina, dalam adjektif, dan semua akhiran sendiri dalam konjugasi verba. Sufiks ini, sampai saat ini masih terdapat di akhir kata, kemudian dinamakan derivasional, dan menggantikan dalam susunan yang dibangun.

\footnotetext{
${ }^{4}$ Helene Huot, Morphologie (Paris: Armand Colin, 2001), hlm. 25.
} 
Berdasarkan pernyataan di atas dapat dinyatakan bahwa perbedaan infleksi dan derivasi itu perlu dipahami dengan lebih cermat. Perbedaan karakteristik dari derivasi dan infleksi dipaparkan oleh Nida ${ }^{5}$ sebagai berikut.

Tabel 1. Perbedaan antara Infleksi dan Derivasi

\begin{tabular}{|c|c|c|}
\hline \multicolumn{2}{|r|}{ Derivational Formations } & Inflectional Formation \\
\hline 1. & $\begin{array}{l}\text { Belong to substantially the same general } \\
\text { external distribution classes as the } \\
\text { simplest member of the class in } \\
\text { question. }\end{array}$ & $\begin{array}{l}\text { Do not belong to substantially the } \\
\text { same general external } \\
\text { distribution } \\
\text { classes as the simplest member of } \\
\text { the class in question. }\end{array}$ \\
\hline 2. & Tend to be "inner" formations. & Tend to be "outer" formations. \\
\hline 3. & Tend to be statistically more numerous. & $\begin{array}{l}\text { Tend to be statistically less } \\
\text { numerous }\end{array}$ \\
\hline 4. & $\begin{array}{l}\text { Have derivational morphemes with } \\
\text { more restricted distribution }\end{array}$ & $\begin{array}{l}\text { 4. Have inflectional morphemes } \\
\text { with more extensive distribution. }\end{array}$ \\
\hline 5. & $\begin{array}{l}\text { May exhibit changes in major } \\
\text { distribution class membership. }\end{array}$ & $\begin{array}{l}\text { Exhibit no changes in major } \\
\text { distribution class membership. }\end{array}$ \\
\hline
\end{tabular}

Berdasarkan uraian tabel di atas, akan terlihat senada dengan tulisan Edi Subroto (1987) menjelaskan bahwa proses infleksi menghasilkan pembentukan infleksional dan proses derivasi menghasilkan pembentukan derivasional. ${ }^{6}$ Perihal perbedaan antara keduanya, Nida menguraikan sebagai berikut (masih dalam Edi Subroto 1987) sebagai berikut:

(1) Pembentukan derivasional termasuk jenis kata yang sama dengan kata tunggal (dari suatu sistem jenis kata tertentu) (misalnya, singer (nomina) dari (to) sing (verba)) termasuk jenis kata yang sama dengan boy (nomina)), sedangkan pembentukan infleksional tidak (misalnya, verba kompleks atau polimorfemis walked tidak termasuk jenis kata yang sama dengan verba tunggal yang mana pun).

(2) Secara statistik, afiks derivasional lebih beragam (misalnya, dalam bahasa Inggris terdapat afiks-afiks pembentuk nomina: -er, -ment, -ion, -ation, -ness (singer, arrangement, correction, nasionalization, stableness); sedangkan afiks

\footnotetext{
${ }^{5}$ Eugene A. Nida, Morphology The Descriptive Analysis of Words (Ann Arbor: The University of Michigan Press. 1962), hlm. 99.

${ }^{6}$ Edi Subroto, "Infleksi dan Derivasi: Kemungkinan Penerapannya dalam Morfologi Bahasa Indonesia" Linguistik Indonesia, Vol. 5 No. 10, 1987, hlm. 26-32.
} 
FITR AH Jurnal Kajian Ilmu-ilmu Keislaman

Vol. 03 No. 1 Juli 2017

infleksional dalam bahasa Inggris kurang beragam atau tertentu: -s, -ed1, ed2, -ing (walks, walked1, walked2, walking).

(3) Afiks-afiks derivasional dapat mengubah jenis kata, sedangkan afiks-afiks infleksional tidak.

(4) Afiks-afiks derivasional mempunyai distribusi yang lebih terbatas (misalnya, -er tidak dapat diramalkan selalu terdapat pada morfem dasar), sedangkan afiks infleksional mempunyai distribusi yang lebih luas.

(5) Pembentukan derivasional dapat menjadi dasar bagi pembentukan berikutnya (singer $\rightarrow$ singers), sedangkan pembentukan infleksional tidak.

Selanjutnya masih dalam tulisan Edi Subroto (1987), beliau memaparkan beberapa pendapat para ahli yang menguraikan masalah derivasi dan infleksi di antaranya:

Verhaar menyatakan bahwa derivasi ialah semua perubahan afiksasi yang melampaui identitas kata, sedangkan semua perubahan yang mempertahankan identitas kata disebut infleksi.7 Prinsip yang diikuti ialah setiap berpindah jenis kata (pembentukan yang menghasilkan jenis kata berbeda) selalu berarti pula berpindah identitas leksikalnya (menulis termasuk verba, penulis termasuk nomina), tetapi tidak sebaliknya setiap berpindah identitas leksikal berarti pula berpindah jenis kata. Misalnya, berangkat (verba) dan memberangkatkan (verba). Keduanya termasuk verba, tetapi identitas leksikalnya berbeda sehingga termasuk derivasional. Kata berangkat termasuk tak transitif, sedangkan memberangkatkan termasuk transitif. Identitas leksikal kedua verba itu berbeda karena referen atau situasi yang ditunjuknya berbeda. Dengan demikian, dapat dinyatakan bahwa -kan pada memberangkatkan adalah afiks yang mentransitifkan. Perihal afiks me(N)- pada memberangkatkan, yang dapat diramalkan dapat digantikan di-, ku-, kau- semata-mata penanda gramatikal, yaitu menyatakan bahwa kalimatnya berfokus pelaku.

Melengkapi uraian tentang seperangkat kriteria operasional untuk membedakan derivasi dari infleksi, Bauer menyatakan bahwa derivasi adalah proses morfemis yang menghasilkan leksem baru, sedangkan infleksi ialah proses morfemis yang menghasilkan bentuk-bentuk kata yang berbeda dari sebuah leksem yang sama. ${ }^{8}$ Sementara itu, menurut Marchand morfem-morfem infleksional menghasilkan bentuk-bentuk yang berbeda dari sebuah kata yang

\footnotetext{
${ }^{7}$ J.W.M. Verhaar, Pengantar Lingguistik (Yogyakarta: Gadjah Mada University Press, 1988), hlm. 65.

${ }^{8}$ Bauer, Introducing Linguistic, 2003, hlm. 91
} 
sama, tidak membentuk sebuah unit leksikal yang baru. Dengan demikian, morfem infleksional tidak relevan bagi pembentukan kata. ${ }^{9}$ Dengan rumusan lain, infleksi adalah bentuk-bentuk kata yang berbeda dari paradigm yang berbeda. ${ }^{10}$ Yang dimaksud dengan leksem dalam rumusan itu ialah satuan leksikal abstrak, yang terkecil baik tunggal maupun kompleks dari bentukbentuk kata dalam sebuah paradigma. ${ }^{11}$ Leksem itu biasanya dilambangkan dengan huruf besar. Misalnya, bentuk-bentuk verba dalam bahasa Inggris:

(I) work,

(He) works,

(I) worked,

(He has) worked,

(He is) working,

adalah bentuk-bentuk kata yang berbeda dari leksem WORK. Dari leksem itu dapat dibentuk leksem baru WORKER yang termasuk nomina. Pembentukan dari work $\rightarrow$ worker 'buruh, pekerja, karyawan' termasuk derivasional. Kata benda derivatif worker dapat dibentuk menjadi kategori jamak workers. Bentukbentuk kata worker (tunggal) dan workers adalah bentuk-bentuk kata yang berbeda dari leksem WORKER. Terdapatnya bentuk-bentuk kata yang berbeda itu (work, works, worked, working, worker, workers) adalah untuk memenuhi kaidahkaidah gramatikal yang bersifat dapat diramalkan. Misalnya, kalau terdapat verba talk, maka terdapatnya bentuk-bentuk kata: talks, talked, talking, bersifat dapat diramalkan, kalau terdapat speaker terdapatnya bentuk speakers bersifat dapat diramalkan. Ciri keteramalan itu merupakan penanda pembentukan infleksional yang penting.

Kemudian, kemungkinan penerapan konsep infleksi dan derivasi untuk memerikan morfologi bahasa Indonesia dijelaskan dalam tulisan Edi Subroto ${ }^{12}$ yang mengatakan bahwa setiap proses morfemis yang menghasilkan jenis kata yang berbeda (pembentukan derivasional).

Dalam pada itu, setiap proses morfologis yang termasuk pembentukan drerivasional tidak selalu ditandai dengan berpindahnya jenis kata. Misalnya, kata lurah dan kelurahan. Kedua kata itu termasuk nomina, tetapi identitas

\footnotetext{
${ }^{9}$ Marchand Hans, The Categories and Types of Present-Day English Word Formation: Synchronic Diachronic Approach (Munchen: CH. Bek'sche Verlagsbuchhanlung, 1969), hlm. 4.

${ }^{10}$ P. H. Matthews, Morphology: An Introduction to The Theory of Word Structure (London: Cambridge University Press, 1974), hlm. 34.

${ }^{11}$ Matthews, Morfology ......1974, hlm. 38

${ }^{12}$ Subroto, "Infleksi dan Derivasi...", Linguistik Indonesia,.... ., 1987, hlm. 33.
} 
FITR AH Jurnal Kajian Ilmu-ilmu Keislaman Vol. 03 No. 1 Juli 2017

leksikalnya berbeda. Kata lurah mengacu kepada seseorang (insan) yang menjabat jabatan tertentu, sedangkan kelurahan tidak mengacu kepada seseorang, melainkan pada 'seluk-beluk atau perihal urusan kedinasan'. Jadi, bersifat bukan insan. Oleh karena itu, referen kedua kata itu pasti berbeda atau sesuatu (yang bersifat di luar bahasa) yang ditunjuk kedua kata itu berbeda. Dengan demikian, pembentukan kata kelurahan itu termasuk derivasional.

\section{Paradigma Dasar Verba HENTI: Infleksi dan Derivasi}

Menurut Edi Subroto, sebuah afiks termasuk infleksional kalau di dalam suatu paradigma diramalkan dapat digantikan afiks infleksional yang lain. Dengan demikian, juga terdapat keteraturan makna gramatikal di dalam paradigma infleksional. Ciri-ciri yang demikian tidak terdapat pada paradigma derivasional. Dengan titik tolak tersebut akan dicoba untuk memerikan paradigma infleksional dan derivasional dalam bahasa Indonesia. Paradigma dari dasar HENTI yang merupakan verba kelas II yang intransitif akan dianalisis sebagai berikut.

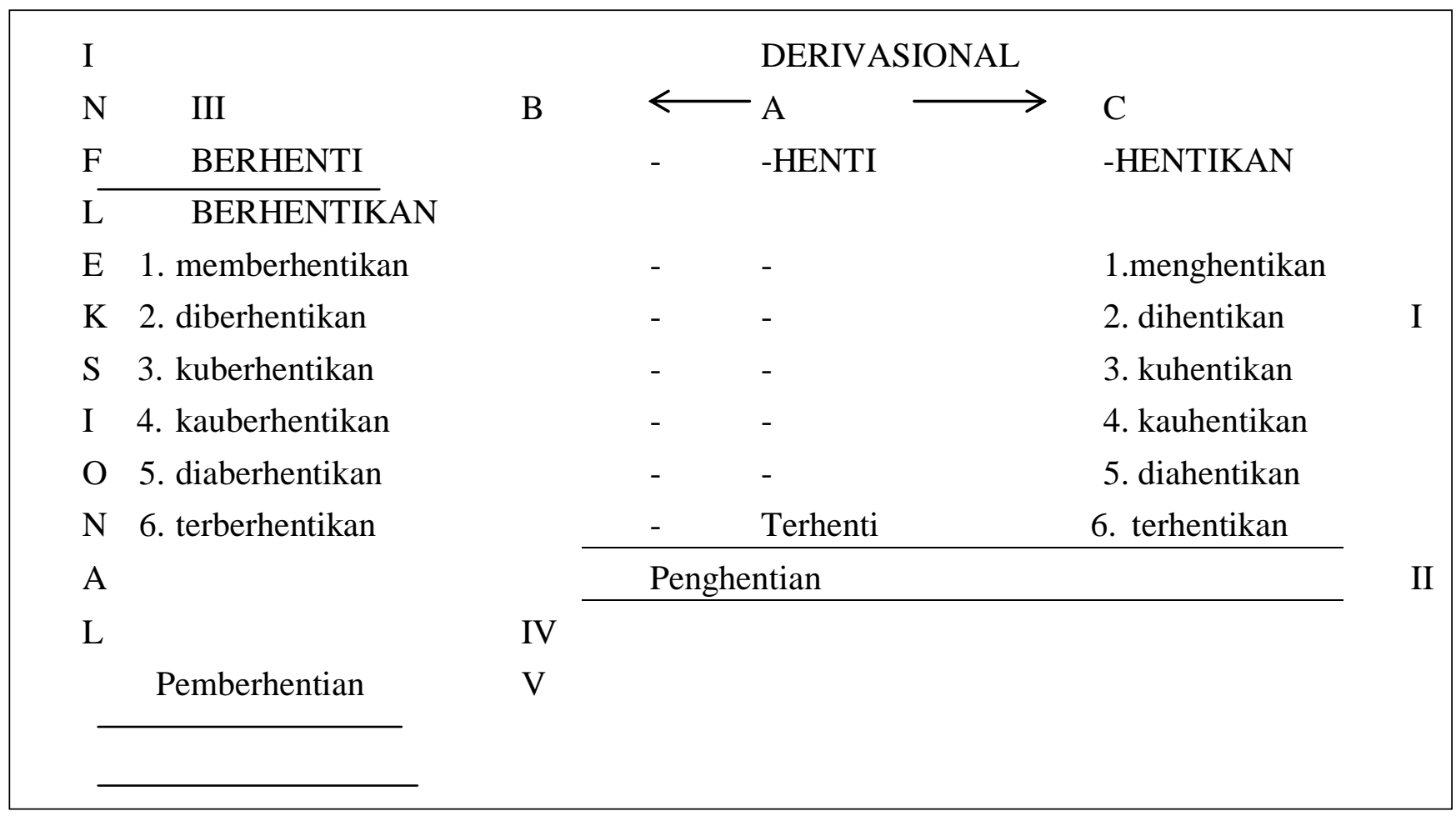

Bagan 1. Paradigma Dasar Verba Henti

Penjelasan paradigma dasar verba henti di atas akan dipaparkan sebagai berikut:

\section{Paradigma I}


Paradigma I terdapat tiga kolom, kolom A (verba dasar henti) ditemukan hanya satu bentuk infleksi pada baris 6 yaitu terhenti yang menyatakan ketidaksengajaan (dalam hal ini tidak sengaja berhenti), sementara itu, baris 1 sampai dengan 5 mengalami kendala bentuk dan kendala semantis yang tidak berterima. Kolom B (tidak ditemukan karena mengalami kendala bentuk, yaitu dasar henti sudah berakhir dengan bunyi /i/, sehingga tidak dapat digabung antara verba dasar henti dengan sufiks -i). Sedangkan kolom $C$ (verba dasar henti yang digabung dengan sufiks -kan). Masing-masing kolom (A, B, C) tidak semua memiliki proses infleksional ke bawah yang dapat diramalkan (predictable) karena kendala semantis dan ideosinkretis (gejala keanehan bentuk) yang tidak lazim, maka hanya kolom C (leksem HENTIKAN) saja yang mengalami proses infleksional. Leksem HENTIKAN termasuk verba transitif dengan ciri semantis benefaktif. Adapun bentuk-bentuk infleksi yang dapat diramalkan dari leksem HENTIKAN adalah: menghentikan, dihentikan, kuhentikan, kauhentikan, diahentikan, dan terhentikan.

Selanjutnya pada kolom C, bentuk kata dengan formula meng-D-kan sebagai bentuk pada baris 1 diramalkan dapat digantikan dengan prefiks di-Dkan pada baris 2, ku-D-kan pada baris 3, kau-D-kan pada baris 4, dia-Dkan pada baris 5, dan ter-D-kan pada baris 6 . Kemunculan masing-masing bentuk meng-D-kan, di-D-kan, ku-D-kan, kau-D-kan, dia-D-kan, dan ter-Dkan dari setiap kolom dapat diramalkan berdasarkan kaidah gramatikal tertentu. Bentuk baris 1 terdapat apabila berfokus pada agen, sedangkan baris 2-5 terdapat bila berfokus pada pasien. Baris 2-5 menyatakan 'kesengajaan'. Baris 2 berbeda dari 3-5 karena di dalam baris 3-5 'pelaku tampak di dalam bentuk', sedangkan baris 2 'pelaku tidak tampak dalam bentuk', baris 3 pelaku adalah persona pertama tunggal lekat kiri (pembicara), baris 4 pelaku adalah persona kedua tunggal lekat kiri, baris 5 pelaku adalah persona ketiga tunggal lekat kiri, baris 6 menyatakan 'ketidaksengajaan oleh agentif'. Kolom C mengandung ciri semantik kausatif.

Berikutnya, verba infleksi yang diturunkan pada kolom $C$ yaitu leksem HENTIKAN tadi dicobakan dalam kalimat berikut.

Kolom A:

Baris 6: Mobil itu terhenti oleh sekawanan bebek yang melintasi jalan. 
FITR AH Jurnal Kajian Ilmu-ilmu Keislaman

Vol. 03 No. 1 Juli 2017

Verba terhenti pada kalimat di atas adalah mobil (agentif) tidak sengaja berhenti karena menghindar dari sekawanan bebek yang melintasi jalan.

Kolom C:

Baris 1: Polisi menghentikan segerombolan begal motor yang membuat kerusuhan.

Verba menghentikan menyatakan kesengajaan polisi (agentif) membuat orang lain berhenti karena suatu alasan, dalam hal ini karena segerombolan begal motor yang membuat kerusuhan.

Baris 2: Kegiatan bazar sembako murah dihentikan pemerintah karena waktu sewa tempat telah habis.

Verba dihentikan menyatakan bahwa kegiatan bazar (pasientif-pelaku yang tidak tampak pada bentuk) yang mengalami keadaan berhenti dengan sengaja karena orang lain akibat suatu alasan yaitu waktu sewa tempat telah habis.

Baris 3: Kemarin, kuhentikan langkah kakiku di depan sebuah toko kue yang lezat.

Verba kuhentikan menyatakan kesengajaan untuk menghentikan langkah kaki oleh pronomina pertama tunggal lekat kiri (pasientifpelaku yang tampak pada bentuk) karena melihat sebuah toko kue yang lezat.

Baris 4: Saya melihat kauhentikan sepeda itu karena bannya bocor.

Verba kauhentikan menyatakan kesengajaan untuk menghentikan sepeda oleh pronomina kedua tunggal lekat kiri (pasientif- pelaku yang tampak pada bentuk) karena ban sepeda tersebut bocor.

Baris 5: Pemuda itu berniat mengejar taksi yang telah diahentikan tadi.

Verba diahentikan menyatakan kesengajaan untuk mengejar taksi yang yang telah dihentikan oleh pronomina ketiga tunggal lekat kiri (pasientif-pelaku yang tampak pada bentuk) karena niat pemuda tersebut.

Baris 6: Acara seminar nasional itu terhentikan oleh waktu.

Verba terhentikan menyatakan ketidaksengajaan untuk menghentikan acara seminar nasional tersebut (kausatif) akibat waktu yang telah ditetapkan.

\section{Paradigma II}


Pada paradigma II mengalami proses derivasi karena terdapat satu nomina deverbal yang dirurunkan dari leksem HENTI yaitu penghentian. Penghentian memiliki ciri semantik 'hal yang membuat berhenti'. Bila dibuat dalam kalimat maka akan seperti berikut:

Para aktivis berjuang untuk penghentian diskriminasi HAM yang timbul belakangan ini.

Verba penghentian menyatakan kesengajaan yang berkaitan dengan hal untuk menghentikan (proses) diskriminasi HAM yang timbul belakangan ini.

\section{Paradigma III}

Pada paradigma III terdapat leksem BERANGKAT yang menyatakan perbuatan berangkat yang tidak transitif, kemudian diturunkan menjadi leksem BERANGKATKAN yang menyatakan verba transitif dengan ciri semantis benefaktif. Leksem BERANGKAT berdiri sendiri dan tidak ditemukan proses infleksional ke bawah karena kendala semantis. Namun, leksem BERHENTIKAN termasuk verba transitif dengan ciri semantis benefaktif dan dapat diramalkan (predictable) proses infleksinya ke bawah, yaitu: memberhentikan, diberhentikan, kuberhentikan, kauberhentikan, diaberhentikan, dan terberhentikan.

Selanjutnya pada kolom ini, bentuk kata dengan konfiks mengber-D-kan sebagai bentuk pada baris 1 diramalkan dapat digantikan dengan prefiks di-ber-D-kan pada baris 2, ku-ber-D-kan pada baris 3, kau-ber-D-kan pada baris 4, dia-ber-D-kan pada baris 5, dan ter-ber-Dkan pada baris 6 . Kemunculan masing-asing bentuk meng-D-kan, di-berD-kan, ku-ber-D-kan, kau-ber-D-kan, dia-ber-D-kan, dan ter-ber-D-kan dari setiap kolom dapat diramalkan berdasarkan kaidah gramatikal tertentu. Bentuk baris 1 terdapat apabila berfokus pada agen, sedangkan baris 2-5 terdapat bila berfokus pada pasien. Baris 2-5 menyatakan 'kesengajaan'. Baris 2 berbeda dari 3-5 karena di dalam baris 3-5 'pelaku tampak di dalam bentuk', sedangkan baris 2 'pelaku tidak tampak dalam bentuk', baris 3 pelaku adalah persona pertama tunggal lekat kiri (pembicara), baris 4 pelaku adalah persona kedua tunggal lekat kiri, baris 5 pelaku adalah persona ketiga tunggal lekat kiri, baris 6 menyatakan 'ketidaksengajaan oleh agentif' dengan ciri semantis kausatif. 
FITR AH Jurnal Kajian Ilmu-ilmu Keislaman

Vol. 03 No. 1 Juli 2017

Berikutnya, verba infleksi yang diturunkan pada paradigma III ini yaitu leksem BERHENTIKAN tadi dicobakan dalam kalimat berikut.

Baris 1: Ibu memberhentikan asisten rumah tangga yang tidak jujur.

Verba memberhentikan menyatakan unsur kesengajaan berupa verba aktif transitif dengan ciri semantis benefaktif karena verba ini membutuhkan kehadiran objek setelahnya dan hal itu dilakukan untuk orang lain. Dalam hal ini yang memberikan perlakuan berhenti pada asisten rumah tangga yang tidak jujur adalah ibu (agentif).

Baris 2: Tito diberhentikan oleh bosnya karena tidak disiplin.

Verba diberhentikan menyatakan unsur kesengajaan dalam bentuk verba pasif transitif dengan ciri semantis benefaktif karena verba ini membutuhkan penjelasan setelahnya karena Tito (pasientif-pelaku tidak tampak pada bentuk) dibuat menjadi berhenti oleh bosnya.

Baris 3: Sengaja kuberhentikan anak itu agar dia sadar akan sikapnya yang arogan.

Verba kuberhentikan menyatakan kesengajaan oleh pasientifpelaku tampak pada bentuk yang berasal dari pronomina pertama tunggal lekat kiri menunjukkan verba aktif transitif dengan ciri semantis benefaktif. Hal ini ditandai karena ada unsur kesengajaan untuk memberhentikan seseorang atas sikap buruknya.

Baris 4: Saya kecewa melihat kauberhentikan pegawai terbaikmu.

Verba kauberhentikan menyatakan unsur kesengajaan oleh pasientif-pelaku tampak pada bentuk yang dilakukan oleh pronomina kedua tunggal lekat kiri. Hal ini merupakan verba aktif transitif dengan ciri semantis benefaktif, karena membuat seseorang menjadi berhenti dari pekerjaannya.

Baris 5: Setelah sepuluh tahun bekerja diaberhentikan staf yang paling setia padanya.

Verba diaberhentikan menyatakan unsur kesengajaan yang dilakukan oleh pasientif-pelaku tampak dalam bentuk yaitu pronomina ketiga tunggal lekat kiri yang merupakan verba aktif transitif dengan ciri semantis benefaktif. Hal ini menyatakan 
seseorang telah diberhentikan dengan sengaja tanpa melihat kesetiaan dan prestasinya.

Baris 6: Dia tidak menyadari kalau anggota timnya telah terberhentikan oleh sistem data base yang telah kadaluwarsa.

Verba terberhentikan menunjukkan unsur ketidaksengajaan dalam memberhentikan seseorang. Dalam kalimat ini Dia (pasientif dengan ciri semantis kausatif) tidak menyadari kalau sistem data base yang telah kadaluwarsa dapat membuat anggota timnya berhenti begitu saja.

\section{Paradigma IV}

Pada paradigma ini tidak ditemukan dalam paradigma dasar verba henti.

\section{Paradigma V}

Pada paradigma $\mathrm{V}$ merupakan proses derivasi karena terdapat satu nomina deverbal yang dirurunkan dari leksem BERHENTI yaitu pemberhentian. Penghentian memiliki ciri semantik 'tempat yang membuat berhenti'. Bila dibuat dalam kalimat maka akan seperti berikut: Pengemudi Batik Solo Trans menurukan penumpang di pemberhentian selanjutnya. Verba pemberhentian menyatakan kesengajaan yang berkaitan dengan hal yang membuat berhenti (pasientif) bagi penumpang Batik Solo Trans yang mau turun selanjutnya.

Kemudian, untuk memudahkan formula paradigma dasar verba henti akan disajikan dalam bentuk tabel 2. sebagai berikut.

\section{Tabel 2. Formula Paradigma Dasar Verba Henti}

\begin{tabular}{|c|c|c|c|c|}
\hline Paradigma & A & B & C & Baris \\
\hline \multirow{4}{*}{} & D & - & -D-kan & 0 \\
\cline { 2 - 5 } & - & - & meng-D-kan & 1 \\
\cline { 2 - 5 } & - & - & di-D-kan & 2 \\
\cline { 2 - 5 } & - & - & ku-D-kan & 3 \\
\cline { 2 - 5 } & - & - & kau-D-kan & 4 \\
\cline { 2 - 5 } & - & - & dia-D-kan & 5 \\
\cline { 2 - 5 } & ter-D & - & ter-D-kan & 6 \\
\hline \multirow{3}{*}{ II } & \multicolumn{3}{|l}{ Peng-D-an } & 7 \\
\hline \multirow{3}{*}{ III } & \multicolumn{3}{|l}{} & 9 \\
\cline { 2 - 5 } & ber-D & ber-D-kan & \\
\hline
\end{tabular}


FITR AH Jurnal Kajian Ilmu-ilmu Keislaman

Vol. 03 No. 1 Juli 2017

\begin{tabular}{|c|l|c|}
\hline \multirow{2}{*}{} & meng-ber-D-kan & 10 \\
\cline { 2 - 3 } & di-ber-D-kan & 11 \\
\cline { 2 - 3 } & ku-ber-D-kan & 12 \\
\cline { 2 - 3 } & kau-ber-D-kan & 13 \\
\cline { 2 - 3 } & dia-ber-D-kan & 14 \\
\cline { 2 - 3 } & ter-ber-D-kan & 15 \\
\hline \multirow{2}{*}{ IV } & pem-ber-D-an & 16 \\
\hline V & & 17 \\
\hline
\end{tabular}

(Diadaptasi dari Dwi Purnanto. ${ }^{13}$,

Berdasarkan tabel 2. di atas, untuk formula paradigma dasar verba henti yang produktif dan dapat diramalkan (predictable) proses infleksionalnya adalah kolom C (-D-kan) pada paradigma I, untuk kolom A (-D) hanya pada ter-D yang dapat berterima, selainnya terkena kendala bentuk dan semantis, untuk kolom $B$, mengingat kendala bunyi yang sudah berakhiran /i/ dan juga kendala bentuk serta kendala semantis, maka kolom ini tidak produktif dan tidak dapat diramalkan. Kemudian pada paradigma III yang juga mengalami hal yang sama dengan paradigma I kolom C, produktif dan dapat diramalkan (predictable) proses infleksionalnya. Sementara itu, paradigma II dan V mengalami proses derivasional yang tidak produktif yaitu terbentuknya nomina deverbal. Sedangkan paradigm IV tidak ditemukan terjadinya proses derivasional maupun infleksional karena kendala bentuk dan kendala semantis.

\section{PENUTUP}

Berdasarkan analisis yang telah dilakukan pada pembahasan sebelumnya, maka dapat disimpulkan bahwa paradigma yang ditemukan dalam dasar verba henti ada empat paradigma, yaitu paradigma I, paradigma II, paradigma III, dan paradigma V. Hal ini terjadi karena dasar henti merupakan jenis verba kelas II yang tergolong dalam verba intransitif. Namun, pada paradigma I, kolom A terdapat satu proses infleksional yaitu terhenti yang menyatakan ketidaksengajaan, sedangkan kolom $C$ terdapat proses infleksional yang lengkap yang produktif dan dapat diramalkan (predictable) dan menyatakan verba aktif transitif dengan ciri semantis benefaktif kecuali untuk dihentikan menyatakan verba pasif transitif dengan ciri semantis benefaktif juga, yang

\footnotetext{
${ }^{13}$ Dwi Purnanto, "Kajian Morfologi Derivasional dan Infleksional dalam Bahasa Indonesia" Kajian Linguistik dan Sastra, Vol. 18, No. 35, 2006, hlm. 136-152.
} 
terdiri dari menghentikan, dihentikan, kuhentikan, kauhentikan, diahentikan, dan terhentikan. Pada paradigma II terjadi proses derivasional yang tidak produktif karena hanya terdapat pada kata penghentian yang menyatakan 'hal untuk menghentikan' yang merupakan nomina deverbal dari dasar henti. Paradigma III ditemukan proses infleksional dengan verba aktif transitif dengan ciri semantis benefaktif yang lengkap, kecuali untuk diberhentikan merupakan verba pasif transitif dengan ciri semantis benefaktif, produktif, dan dapat diramalkan (predictable) yang terdiri dari: memberhentikan, diberhentikan, kuberhentikan, kauberhentikan, diaberhentikan, dan terberhentikan. Paradigma V juga merupakan proses derivasional juga tidak produktif, hanya terdapat pada kata pemberhentian yang berasal dari kata berhenti yang merupan nomina deverbal dan memiliki ciri semantis 'hal yang membuat untuk berhenti'.

Dengan demikian, putus asa yang berasal dari berhenti berharap tadi dapat dimaknai secara mendalam pada paradigma leksem HENTI. Perlunya memahami leksem ini secara morfologis agar gejala ideonsinkretis dalam kaidah derivasional dan infleksional dapat bermanfaat dalam kebutuhan berkomunikasi yang berorientasi pada hal-hal yang positif. Akhirnya, komunikasi dengan penggunaan diksi positif akan mendorong seseorang untuk memiliki pola pikir dan cara hidup yang lebih baik sesuai dengan nilai-nilai Islam. 
FITR AH Jurnal Kajian Ilmu-ilmu Keislaman

Vol. 03 No. 1 Juli 2017

\section{DAFTAR PUSTAKA}

Bauer Laurie, Introducing Linguistic Morphology, Edinburgh: Edinburgh University Press, 2003.

Verhaar J.W.M, Asas-asas Linguistik Umum, Yogyakarta: Gadjah Mada University, 2008.

Yule, George, The study of language, Cambridge: Cambridge University Press, 1996.

Huot, Helene, Morphologie, Paris: Armand Colin, 2001.

Nida, Eugene A, Morphology The Descriptive Analysis of Words, Ann Arbor: The University of Michigan Press. 1962.

Subroto, Edi, “Infleksi dan Derivasi: Kemungkinan Penerapannya dalam Morfologi Bahasa Indonesia" Linguistik Indonesia, Vol. 5 No. 10, 1987.

Verhaar, J.W.M, Pengantar Lingguistik, Yogyakarta: Gadjah Mada University Press, 1988.

Hans, Marchand, The Categories and Types of Present-Day English Word Formation: Synchronic -Diachronic Approach, Munchen: CH. Bek'sche Verlagsbuchhanlung, 1969.

Matthews, P. H, Morphology: An Introduction to The Theory of Word Structure (London: Cambridge University Press, 1974.

Purnanto, Dwi, "Kajian Morfologi Derivasional dan Infleksional dalam Bahasa Indonesia" Kajian Linguistik dan Sastra, Vol. 18, No. 35, 2006. 